\title{
Ghrelin gene products rescue cultured adult rat hippocampal neural stem cells from high glucose insult
}

\author{
Sehee Kim¹, Chanyang Kim¹ and Seungjoon Park² \\ 'Department of Biomedical Science, Graduate School, Kyung Hee University, Seoul, Korea \\ 2Department of Pharmacology and Medical Research Center for Bioreaction to ROS and \\ Biomedical Science Institute, School of Medicine, Kyung Hee University, Seoul, Korea
}

Correspondence should be addressed to S Park Email sjpark@khu.ac.kr

\begin{abstract}
Adult hippocampal neurogenesis is decreased in type 2 diabetes, and this impairment appears to be important in cognitive dysfunction. Previous studies suggest that ghrelin gene products (acylated ghrelin (AG), unacylated ghrelin (UAG) and obestatin (OB)) promote neurogenesis. Therefore, we hypothesize that ghrelin gene products may reduce the harmful effects of high glucose (HG) on hippocampal neural stem cells (NSCs). The aim of this study was to investigate the role of these peptides on the survival of cultured hippocampal NSCs exposed to HG insult. Treatment of hippocampal NSCs with AG, UAG or OB inhibited HG-induced cell death and apoptosis. Exposure of cells to the growth hormone secretagogue receptor $1 \mathrm{a}$ antagonist abolished the protective effects of AG against HG toxicity, whereas those of UAG or OB were preserved. All three peptides attenuated HG-induced decrease in BrdU-labeled and phosphohistone-H3-labeled cells. We also investigated the effects of ghrelin gene products on the regulation of apoptosis at the mitochondrial level. AG, UAG or OB rescued hippocampal NSCs from HG insult by inhibiting intracellular and mitochondrial reactive oxygen species generation and stabilizing mitochondrial transmembrane potential. In addition, cells treated with ghrelin gene products showed an increased $\mathrm{BCl}-2$ and decreased Bax levels, thereby increasing the $\mathrm{Bcl}-2 / \mathrm{Bax}$ ratio, inhibiting cytochrome $\mathrm{c}$ release and preventing caspase- 3 activation. Finally, AG-, UAG- or OB-mediated protection was dependent on the activities of adenosine monophosphate-activated protein kinase/uncoupling protein 2 pathway. Our data indicate that ghrelin gene products may act as survival factors that preserve mitochondrial function and inhibit oxidative stress-induced apoptosis.
\end{abstract}

Journal of Molecular Endocrinology (2016) 57, 171-184

\section{Introduction}

Two major molecular forms of ghrelin are found in plasma, acylated ghrelin (AG) and unacylated ghrelin (UAG) (Hosoda et al. 2000). AG is a 28-amino acid peptide, which shows a unique posttranslational modification of $O$ - $n$-octanolyation at Ser3. AG was initially discovered as an endogenous ligand for the growth hormone $(\mathrm{GH})$ secretagogue receptor 1a (GHS-R1a) in 1999 (Kojima et al. 1999). AG stimulates $\mathrm{GH}$ release and enhances food intake through the activation of GHS-R1a (Kojima et al. 1999). In addition, AG also plays an important role in regulating numerous peripheral functions (Van der Lely et al. 2004, Kojima \& Kangawa 2005). In contrast, UAG, which lacks

Published by Bioscientifica Ltd 
O-n-octanolyation at Ser3, is the most abundant form of ghrelin in plasma and is not able to bind GHS-R1a (Van der Lely et al. 2004). UAG is not just a reservoir of inactive peptides, but both types of ghrelin exert several similar biological activities in vitro and in vivo (Tschop et al. 2000, Wren et al. 2000, Gahete et al. 2014). We and others have reported that AG and UAG show neuroprotective effects by inhibiting apoptotic pathways (Jiang et al. 2006, 2008, Miao et al. 2007, Chung et al. 2008, Hwang et al. 2009). Obestatin (OB), the third ghrelin gene product, is a novel 23-amino acid peptide generated from C-ghrelin peptide. It was originally considered as a physiological inhibitor of AG on food intake (Zhang et al. 2005). OB also showed various biological functions, including promotion of survival of pancreatic $\beta$-cells and human islets (Granata et al. 2008). However, the role of $\mathrm{OB}$ in feeding regulation remains controversial (Nogueiras et al. 2007).

The subgranular zone of the dentate gyrus (DG) in the hippocampus is one of the two well-known regions where neurogenesis persists into adulthood (Zhao et al. 2008). Adult hippocampal neurogenesis deserves particular attention because it is involved in the process of learning, memory and emotional responses (Zhao et al. 2008). It has been shown that ghrelin gene products (AG, UAG and OB) stimulate neurogenesis (Sato et al. 2006, Moon et al. 2009, Chung et al. 2013, Li et al. 2013a, Gargantini et al. 2016). An earlier study reported that AG and UAG increased neurogenesis in the rat fetal spinal cord (Sato et al. 2006). We have reported that AG treatment induces hippocampal neurogenesis in adult mice (Moon etal. 2009). Moreover, we found that ghrelin knockout mice showed lower numbers of progenitor cells in the DG, whereas AG administration restored progenitor cell numbers to those of wild-type controls (Li et al. 2013a). Additionally, we also reported that AG increases cellular proliferation of cultured adult rat hippocampal neural stem cells (NSCs) through the activation of extracellular signal-regulated kinases (ERK) 1/2, phosphoinositide 3-kinase (PI3K)/Akt and signal transducer and activator of transcription 3 signaling pathways (Chung et al. 2013). Recent study demonstrated that $\mathrm{OB}$ promotes the proliferation and survival of adult hippocampal progenitors (Gargantini et al. 2016). Taken together, these observations indicate that ghrelin gene products may promote hippocampal NSCs proliferation and thereby act as neurogenic agents.

Diabetes is a chronic metabolic disorder characterized by hyperglycemia, which is detrimental to cognitive function (Kodl \& Seaquist 2008). Therefore, diabetes often results in increased risk of learning and memory impairment. Decreased hippocampal neurogenesis has been observed in type 1 (Stranahan et al. 2008, Zhang et al. 2008) and type 2 diabetic rats (Lang et al. 2009). It has been implicated that increased reactive oxygen species (ROS) levels and mitochondrial dysfunction inhibit adult hippocampal neurogenesis (Voloboueva \& Giffard 2011). A growing body of evidence indicates that the mitochondria are closely associated with cell death and cell survival (Green \& Reed 1998, Chan 2004). Although the precise mechanisms leading to mitochondrial dysfunction and apoptotic cell death are still unclear, oxidative stress plays an important role in the depolarization of mitochondrial transmembrane potential $\left(\Delta \Psi_{\mathrm{M}}\right)$ and release of cytochrome c from the mitochondria into cytosol (Tabakman et al. 2002, MacGregor et al. 2003, Shen et al. 2004). When released, cytosolic cytochrome c forms a complex with Apaf-1, leading to the activation of caspase- 9 and subsequent activation of downstream apoptotic cascades (Li et al. 1997, Yoshida et al. 1998). Previous numerous in vivo and in vitro studies have shown that high glucose (HG) induces oxidative stress, mitochondrial dysfunction and apoptosis in neurons (Russell \& Feldman 1999, Russell et al. 1999, 2002, Srinivasan et al. 2000). Based on these observations, we hypothesized that ghrelin gene products may promote the survival of adult rat hippocampal NSCs against HG. At present, no data are available on the effects of ghrelin gene products in hippocampal NSCs exposed to HG insult.

It has been reported that AG increases hippocampal adenosine monophosphate-activated protein kinase (AMPK) phosphorylation (Kang et al. 2015). Enhanced expression of uncoupling protein 2 (UCP2), a downstream target of AMPK (Andrews et al. 2008), by AG is known to reduce oxidative stress-induced neuronal injury (Liu et al. 2009). AMPK/UCP2 pathway has been demonstrated to play an important role in regulating the actions of AG in the brain (Andrews et al. 2008, Ronnett et al. 2009). Taken together, the molecules targeting pharmacological intervention of AMPK/UCP2 pathway may be valuable candidates for HG-induced oxidative stress and mitochondrial dysfunction. However, the role of AMPK/UCP2 pathway in AG-, UAG- or OB-mediated inhibition of $\mathrm{HG}$-induced apoptosis has never been investigated. In this study, we examined the effect of $A G$, UAG or OB on the survival of hippocampal NSCs exposed to HG insult. To determine the mechanisms of protection against HG, which are induced by ghrelin gene products, selective inhibitors of AMPK and UCP2 were used. We also investigated the effects of ghrelin gene products on HG-induced oxidative stress and mitochondrial dysfunction.

Published by Bioscientifica Ltd. 


\section{Materials and methods}

\section{Materials}

Rat AG, UAG and OB were obtained from Tocris (Ellisville, MO, USA). D-Lys-3-GHRP-6 was purchased from Bachem (Torrance, CA, USA). Neural stem cell expansion media, DMEM/F12 and B27 supplement were from Gibco/ Invitrogen. B-27 is an optimized serum substitute developed for low-density plating and long-term viability and growth of CNS neurons. AMPK inhibitor, compound C, was from Tocris and UCP2 inhibitor, genipin, was from Sigma-Aldrich. All tissue culture reagents were obtained from Gibco/Invitrogen, and all other reagents were obtained from Sigma-Aldrich unless otherwise indicated.

\section{Adult rat hippocampal neural stem cell cultures and treatments}

Adult rat hippocampal NSCs were obtained from Chemicon (Catalog No. SCR022, Billerica, MA, USA). These cells are ready-to-use primary NSCs isolated from the hippocampus of adult Fisher 344 rats. They were grown in neural stem cell expansion medium containing DMEM/F12 with $17.5 \mathrm{mM}$ glucose, L-glutamine, B27 supplement, $1 \times$ solution of penicillin, streptomycin and fungizone and basic FGF (bFGF, $20 \mathrm{ng} / \mathrm{mL}$ ). Tissue culture plasticwares or glasswares that were used to culture hippocampal NSCs were coated with poly-L-ornithine $(10 \mu \mathrm{g} / \mathrm{mL})$ and laminin $(5 \mu \mathrm{g} / \mathrm{mL})$. The hippocampal NSCs were maintained at $37^{\circ} \mathrm{C}$ in a $5 \% \mathrm{CO}_{2}$ humidified incubator and with a complete change of media containing fresh bFGF every other day and passaged once every 5-6 days. To determine the optimal concentration of glucose, cells were treated with normal glucose $(17.5 \mathrm{mM})$ or $\mathrm{HG}(27.75,41.75$ or $83.75 \mathrm{mM}$ ) for $48 \mathrm{~h}$. To examine if ghrelin gene products protect hippocampal NSCs from HG insult, cells were pretreated with AG (100nM), UAG (100 nM), OB (100 nM) or vehicle (saline) for $1.5 \mathrm{~h}$. This dose was selected based on our preliminary studies showing that it decreased the number of TUNEL-positive cells in hippocampal NSCs exposed to HG insult and it was the lowest dose with the maximum response (Supplementary Fig. 1, see section on supplementary data given at the end of this article). Then, cells were exposed to HG (83.75 mM glucose) for $48 \mathrm{~h}$. To examine whether the effects of ghrelin gene products are exerted through GHS-R1a, cells were incubated with D-Lys-3-GHRP-6 $(200 \mu \mathrm{M})$ or vehicle for $2 \mathrm{~h}$ before treatment with AG, UAG or OB. To determine if AMPK/ UCP2 signaling pathway is involved in the protective effects, mediated by ghrelin gene products, against HG insult, experiments were also performed by adding the following pharmacological inhibitors to culture media: AMPK inhibitor compound $\mathrm{C}(1 \mu \mathrm{M})$ or UCP2 inhibitor genipin $(20 \mu \mathrm{M})$.

\section{Assessment of cell proliferation and mitosis}

Experiments for cell proliferation were performed in 6-well chamber slides. After the completion of HG incubation, cells were treated with $\mathrm{BrdU}(10 \mu \mathrm{M})$ for $4 \mathrm{~h}$ and then fixed with 4\% paraformaldehyde (PFA). Four random fields for each well were chosen under the $20 \times$ objective, and the total number of BrdU-labeled cells was counted by people who were blind to the treatment as reported previously (Chung et al. 2013). The relative numbers of cells in $\mathrm{M}$ phase were estimated using phosphohistone-H3 antibody (1:1000) as a marker. Phosphohistone-H3-labeled cells were counted in three $1 \mathrm{~cm}$ rows in three dishes per group.

\section{Cell death and apoptosis}

Cells viability was measured by the MTT assay. To measure the double-stranded cleavage of DNA, a TUNEL assay was performed using the APO-BrdU TUNEL Assay Kit (Molecular Probes) according to the manufacturer's instructions.

\section{Measurement of ROS production}

Intracellular ROS generation was measured using confocal microscopy on cells stained with the ROS-sensitive fluorescent dye 2',7'-dichlorofluorescein diacetate (DCF-DA) (Sigma-Aldrich). ROS production was assessed on 4-well chamber slides. The cells were incubated with $2.5 \mu \mathrm{M}$ dichlorofluorescein diacetate for $30 \mathrm{~min}$. For the detection of mitochondrial ROS production, we used the mitochondrial-sensitive dye MitoSOX Red (Molecular Probes). Cells were incubated with MitoSOX Red $(3 \mu \mathrm{M})$ for $10 \mathrm{~min}$. Fluorescence was captured using a $40 \times$ objective lens on a Carl Zeiss LSM 700 Meta (Oberkochen, Germany) confocal microscope (485-nm excitation and 535-nm emission). Dichlorofluorescein diacetate and MitoSOX Red fluorescences were quantified from cells of interest using the measurement functions on the Carl Zeiss confocal software.

\section{Assessment of $\Delta \Psi_{M}$}

The $\Delta \Psi_{\mathrm{M}}$ was monitored with the JC-1 reagent in the Mitochondrial Membrane Potential Detection Kit

Published by Bioscientifica Ltd. 
(Stratagene) and confocal microscopy according to the manufacturer's instructions. Briefly, cells were incubated with $1 \times \mathrm{JC}-1$ reagent solution at $37^{\circ} \mathrm{C}$ for 15 min. Culture slides were washed and mounted with PBS, and confocal images were acquired by the Carl Zeiss LSM 700 Meta confocal microscope. The ratio of red to green fluorescence was quantified from cells of interest using the measurement functions on the confocal microscopy software.

\section{Western blot analysis}

Cells were lysed in a buffer containing $20 \mathrm{mM}$ Tris- $\mathrm{HCl}$ (pH 7.4), $1 \mathrm{mM}$ EDTA, $140 \mathrm{mM} \mathrm{NaCl}, 1 \%$ (w/v) Nonidet P-40, $1 \mathrm{mM}$ Na3VO4, $1 \mathrm{mM}$ phenylmethylsulfonyl fluoride, $50 \mathrm{mM} \mathrm{NaF}$ and $10 \mu \mathrm{g} / \mathrm{mL}$ aprotinin. Cell lysates were separated by 12\% SDS-PAGE and electrotransferred to a polyvinylidene difluoride membrane (Bio-Rad). The membranes were soaked in blocking buffer (1× Trisbuffered saline, 1\% BSA and 1\% nonfat dry milk) for $1 \mathrm{~h}$ and incubated overnight at $4^{\circ} \mathrm{C}$ with the primary antibodies against cytochrome c, Bax (Santa Cruz Biotechnology; 1:1000), active caspase-3, Bcl-2, AMPK $\alpha$, phosphor-AMPK $\alpha$ on Thr172 (Cell Signaling; 1:1000) and UCP2 (Abcam). Blots were developed using a peroxidaseconjugated anti-rabbit IgG and a chemiluminescent detection system (Santa Cruz Biotechnology). The bands were visualized using a ChemicDoc XRS system (Bio-Rad) and quantified using Quantity One imaging software (Bio-Rad).

\section{Immunocytochemical detection of Bax translocation and cytochrome $\mathrm{c}$ release}

At the completion of HG exposure, cells were stained with MitoTracker Orange CMTMRos (200 nM, Molecular Probes) for $10 \mathrm{~min}$ at $37^{\circ} \mathrm{C}$ and then fixed with $4 \%$ PFA. Cells were blocked for $1 \mathrm{~h}$ with $1 \%$ BSA and $0.3 \%$ normal goat serum in PBS and incubated with primary antibodies against Bax or cytochrome c (1:1000, Santa Cruz Biotechnology) overnight at $4^{\circ} \mathrm{C}$. Then, cells were incubated with Alexa Fluor 488-conjugated secondary antibody against rabbit IgG for $2 \mathrm{~h}$ at room temperature. The images were captured by the Carl Zeiss LSM 700 Meta confocal microscope.

\section{Statistical analysis}

Data are presented as mean \pm s.E.m. for the four different experiments (each experiment was performed in triplicate). Statistical analysis between groups was performed using one-way ANOVA and Holm-Sidak method for multiple comparisons using SigmaStat for Windows version 3.10 (Systat Software, Inc, Point Richmond, CA, USA). $P<0.05$ was considered statistically significant.

\section{Results}

\section{Ghrelin gene products protect hippocampal NSCs against HG insult}

It should be noted that the concentration of normal glucose $(17.5 \mathrm{mM})$ used in this study was high. To study the responses of neurons under a HG milieu, the glucose levels in the experimental system should imitate those in the brain in vivo. Usually, $5.5 \mathrm{mM}$ glucose is considered as normal concentration of glucose, because the physiological blood glucose concentration in vivo range from 5.5 to $7.0 \mathrm{mM}$. However, it is known that cultured hippocampal NSCs do not grow well in the medium with 5.5 or $7.5 \mathrm{mM}$ glucose, but grew well in the medium with $17.5 \mathrm{mM}$ glucose (Chen et al. 2013). Therefore, we used $17.5 \mathrm{mM}$ glucose as the normal glucose level for hippocampal NSCs in this study. The percentage of viable cells compared with $17.5 \mathrm{mM}$ glucose decreased to $74.6 \%(41.75 \mathrm{mM})$ and $53.8 \%(83.75 \mathrm{mM})$ when cells were exposed for $48 \mathrm{~h}$ to higher concentrations of glucose (Fig. 1A). However, HG (83.75 mM)-induced cell death was significantly reduced by pretreatment with AG, UAG or OB (Fig. 1B). To control for the osmotic effect of HG, hippocampal NSCs were incubated in the presence of increasing concentration of mannitol (10.25 66.25 mM). Mannitol had no effect on cell viability (Fig. 1E), suggesting that HG-induced cell death was independent of an osmotic effect. Next, we investigated the effect of $\mathrm{HG}$ on apoptosis in hippocampal NSCs. The percentage of TUNEL-positive cells was significantly increased in a concentration-dependent manner (Fig. 1C). Pretreatment of cells with ghrelin gene products prevented apoptosis induced by HG (Fig. 1D). To determine whether the anti-apoptotic effect of AG is mediated by its receptor GHS-R1a, hippocampal NSCs were treated with the GHS-R1a-specific antagonist. The exposure of cells to D-Lys-3-GHRP-6 completely abolished the protective effect of AG against HG toxicity (Fig. 1F). In contrast, the antagonist did not alter the anti-apoptotic effect of UAG or OB.

Published by Bioscientifica Ltd. 
A

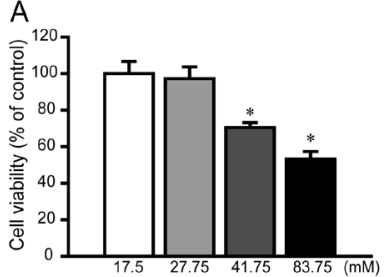

B
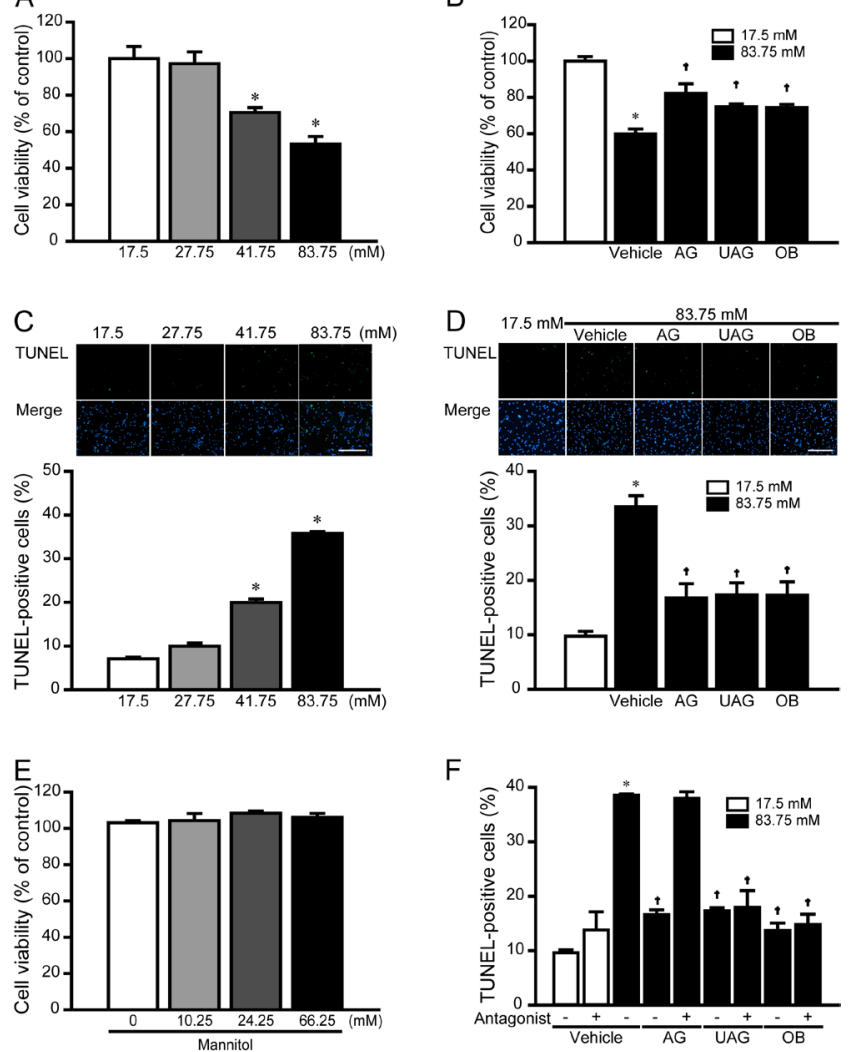

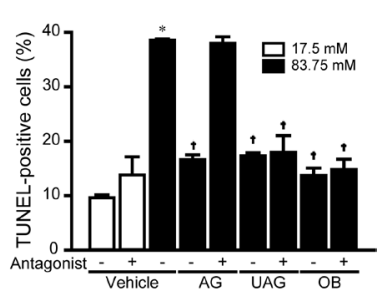

A
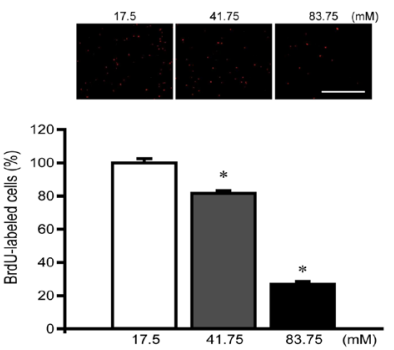

C

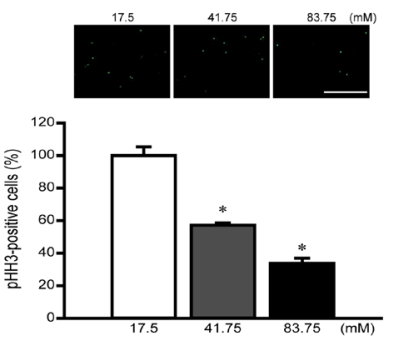

B
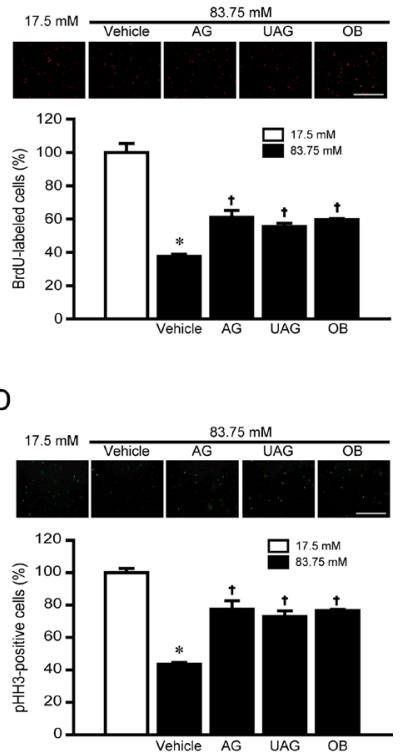

Figure 1

Ghrelin gene products protect hippocampal NSCs against HG insult. (A and C) Cells were exposed to various concentrations of glucose for $48 \mathrm{~h}$. (E) Cells were incubated in the presence of increasing concentration of mannitol (10.25 66.25 mM) for $48 \mathrm{~h}$. (F) Cells were preincubated with vehicle or D-Lys-GHRP-6 $(200 \mu \mathrm{M})$ for $2 \mathrm{~h}$. (B, D and F) Cells were pretreated with vehicle, AG $(100 \mathrm{nM})$, UAG $(100 \mathrm{nM})$ or OB $(100 \mathrm{nM})$ for $1.5 \mathrm{~h}$ and then exposed to $83.75 \mathrm{mM}$ glucose for $48 \mathrm{~h}$. (A, B and E) Cell viability was measured by the MTT assay. (C, D and F) Apoptosis was assessed by TUNEL staining. Values are the mean \pm S.E.M. of four separate experiments performed in triplicate. ${ }^{*} P<0.05$ vs $17.5 \mathrm{mM}$ glucose-treated control; ${ }^{+} P<0.05$ vs vehicle-treated cells exposed to $83.75 \mathrm{mM}$ glucose.

\section{Ghrelin gene products attenuate the inhibitory effect of HG on proliferation and mitosis of hippocampal NSCs}

We examined the proliferative activity of hippocampal NSCs exposed to various concentrations of glucose for $48 \mathrm{~h}$. Analysis of BrdU-labeled cells showed a decrease in cell proliferation in a concentration-dependent manner (Fig. 2A). When the cells were pretreated with ghrelin gene products, HG-induced decrease in BrdU-labeled cells was significantly attenuated (Fig. 2B). Moreover, HG insult inhibited mitosis, because there were $42.7 \%(41.75 \mathrm{mM})$ and $66.3 \%(83.75 \mathrm{mM})$ decreases in the number of cells exhibiting M-phase marker phosphohistone-H3 at $48 \mathrm{~h}$ (Fig. 2C). Pretreatment of cells with AG, UAG or OB increased phosphohistone-H3-positive cells, which were decreased by HG (Fig. 2D).

\section{Figure 2}

Effects of ghrelin gene products on the proliferation and mitosis in hippocampal NSCs exposed to HG insult. (A and C) Cells were exposed to various concentrations of glucose for $48 \mathrm{~h}$. (B and $D)$ Cells were pretreated with vehicle, AG $(100 \mathrm{nM})$, UAG $(100 \mathrm{nM})$ or OB $(100 \mathrm{nM})$ for $1.5 \mathrm{~h}$ and then exposed to $83.75 \mathrm{mM}$ glucose for $48 \mathrm{~h}$. ( $A$ and $B$ ) Representative microscopic images showing BrdU-labeled hippocampal NSCs (upper panel). Scale bar represents $200 \mu \mathrm{M}$. Quantitative analysis (lower panel) showed that the numbers of BrdU-labeled cells were decreased in a concentration-dependent manner $(A)$ and that ghrelin gene products attenuated HG-induced decrease in BrdU-labeled cells (B). (C and D) Representative microscopic images showing phosphohistoneH3-labeled hippocampal NSCs (upper panel). Scale bar represents $200 \mu \mathrm{M}$. Quantitative analysis (lower panel) showed that the numbers of phosphohistone-H3-labeled cells were decreased in a concentrationdependent manner (C) and that ghrelin gene products attenuated HG-induced decrease in phosphohistone-H3-labeled cells (D). Values are the mean \pm s.E.M. of four separate experiments performed in triplicate. ${ }^{*} P<0.05$ vs $17.5 \mathrm{mM}$ glucose-treated control; ${ }^{+} P<0.05$ vs vehicle-treated cells exposed to $83.75 \mathrm{mM}$ glucose.

\section{Ghrelin gene products inhibit HG-induced increase in ROS generation in hippocampal NSCs}

To determine whether ghrelin gene products may inhibit HG-induced cell death by suppression of ROS generation, we examined the changes in ROS levels. Compared with normal glucose controls, cells exposed to HG showed increased ROS production in a concentration-dependent manner (Fig. 3A). In contrast, treatment of cells with $A G, U A G$ or $O B$ significantly reduced the increase in dichlorofluorescein fluorescence induced by HG (Fig. 3B). ROS are located mainly in the mitochondrion of intact cells, and most intracellular ROS are generated from mitochondria (Indo et al. 2007). Therefore, we also measured mitochondrial ROS levels using MitoSOX Red

Published by Bioscientifica Ltd 
as a mitochondrial superoxide indicator. Compared with normal glucose, HG increased mitochondrial ROS levels in a concentration-dependent manner (Fig. 3C), whereas ghrelin gene products significantly reduced the increase in MitoSOX Red fluorescence induced by HG (Fig. 3D).

\section{Ghrelin gene products stabilize $\Delta \Psi_{\mathrm{M}}$}

It is known that $H G$ destabilizes $\Delta \Psi_{\mathrm{M}}$ due to the opening of the mitochondrial permeability transition (PT) pore (Russell et al. 2002). We have reported that AG blocks oxygen-glucose deprivation-induced apoptosis
A
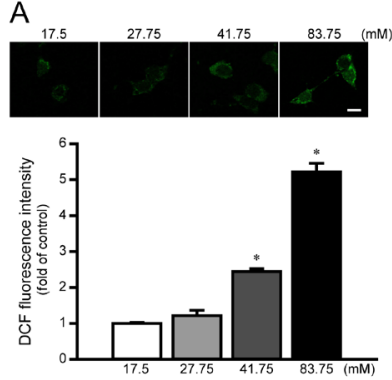

C
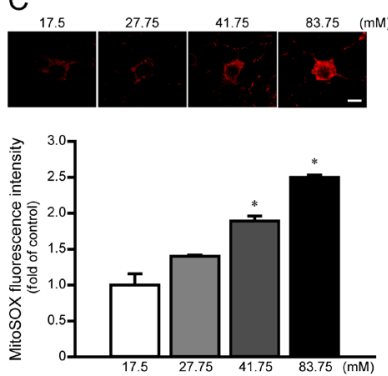

$B$
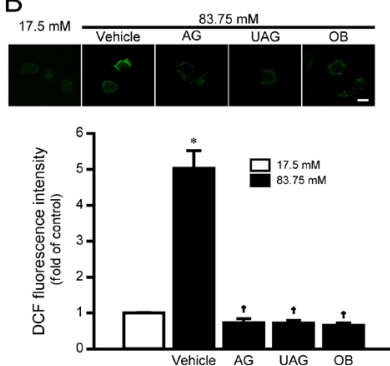

D
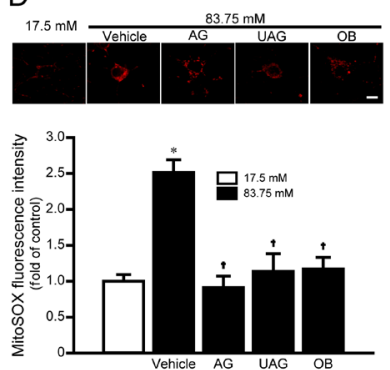

Figure 3

Effects of ghrelin gene products on the intracellular and mitochondrial ROS generation in hippocampal NSCs exposed to HG insult. ( $A$ and $C$ ) Cells were exposed to various concentrations of glucose for $48 \mathrm{~h}$. (B and D) Cells were pretreated with vehicle, AG (100 nM), UAG $(100 \mathrm{nM})$ or $\mathrm{OB}(100 \mathrm{nM})$ for $1.5 \mathrm{~h}$ and then exposed to $83.75 \mathrm{mM}$ glucose for $48 \mathrm{~h}$. (A and B) Intracellular ROS levels were determined using confocal microscopy on cells stained with the ROS-sensitive fluorescent dye DCF-DA. Representative microscopic images showing DCF-DA-stained hippocampal NSCs (upper panel). Scale bar represents $5 \mu \mathrm{M}$. Quantitative analysis (lower panel) showed that DCF fluorescence was increased in a concentration-dependent manner $(\mathrm{A})$ and that ghrelin gene products inhibited HG-induced increase in DCF fluorescence (B).

( $C$ and $D$ ) Mitochondrial ROS levels were determined using confocal microscopy on cells stained with the mitochondrial superoxide indicator MitoSOX Red. Representative microscopic images showing MitoSOX Red-stained hippocampal NSCs (upper panel). Scale bar represents $5 \mu \mathrm{M}$. Quantitative analysis (lower panel) showed that MitoSOX Red fluorescence was increased in a concentration-dependent manner (C) and that ghrelin gene products inhibited HG-induced increase in MitoSOX Red fluorescence (D). Values are the mean \pm S.E.M. of four separate experiments performed in triplicate. ${ }^{*} P<0.05$ vs $17.5 \mathrm{mM}$ glucose-treated control; $+P<0.05$ vs vehicle-treated cells exposed to $83.75 \mathrm{mM}$ glucose.

by preventing mitochondrial depolarization (loss of $\Delta \Psi_{\mathrm{M}}$ ) (Chung et al. 2007). Therefore, we examined the effect of ghrelin gene products on $\Delta \Psi_{\mathrm{M}}$ using JC-1, which shows potential-dependent accumulation in the mitochondria. As shown in Fig. 4A and C, increased glucose load significantly decreased the $\Delta \Psi_{\mathrm{M}}$, as indicated by the marked decreases in green fluorescence. However, when cells were pretreated with AG, UAG or $\mathrm{OB}, \mathrm{HG}$-induced mitochondrial depolarization was inhibited (Fig. 4B and D).

\section{Ghrelin gene products increase Bcl-2 and decrease Bax, thereby increasing the $\mathrm{BCl}-2 / \mathrm{Bax}$ ratio}

AG and UAG are known to inhibit apoptosis by increasing the expression of anti-apoptotic Bcl-2 and decreasing pro-apoptotic Bax expression in neurons exposed to oxygen-glucose deprivation insult (Chung et al. 2007, 2008). To identify changes in protein levels of Bcl-2 and Bax, we conducted a Western blot using lysates extracted from cells exposed to $83.75 \mathrm{mM}$ glucose. We found that HG insult significantly decreased Bcl-2 protein levels in a time-dependent manner (Fig. 5A), whereas pretreatment of cells with ghrelin gene products

A

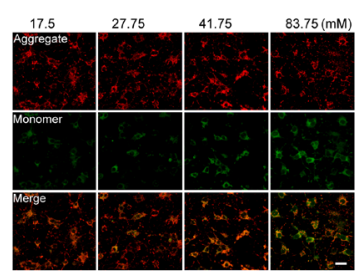

$\mathrm{B}$

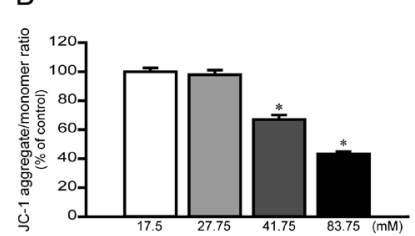

C
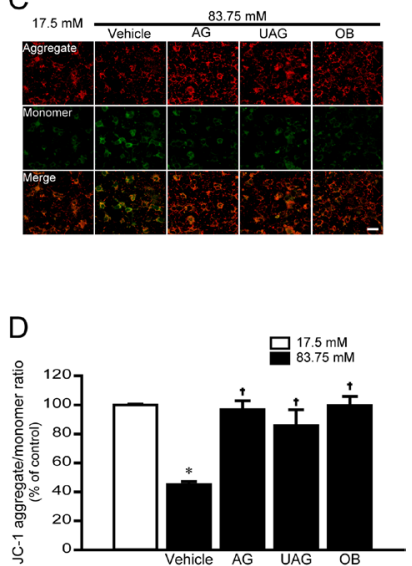

Figure 4

Effect of ghrelin gene products on mitochondrial transmembrane potential $(\Delta \Psi)$ in hippocampal NSCs exposed to HG insult. (A and C) Cells were exposed to various concentrations of glucose for $48 \mathrm{~h}$.

( $B$ and D) Cells were pretreated with vehicle, AG (100 nM), UAG (100 nM) or OB $(100 \mathrm{nM})$ for $1.5 \mathrm{~h}$ and then exposed to $83.75 \mathrm{mM}$ glucose for $48 \mathrm{~h}$. (A and B) The $\Delta \Psi$ was determined by confocal microscopy using JC-1 dye. Mitochondria with a higher membrane potential have a red fluorescence, and those with a lower membrane potential are green. ( $C$ and $D)$ The ratio of red-to-green fluorescence was quantified in cells of interest using the measurement functions in the Carl Zeiss LSM 700 Meta software. Values are the mean \pm S.E.M. expressed as $\%$ of control. $* P<0.05$ vs $17.5 \mathrm{mM}$ glucose-treated control; $+P<0.05$ vs vehicle-treated cells exposed to $83.75 \mathrm{mM}$ glucose.

Published by Bioscientifica Ltd 
A

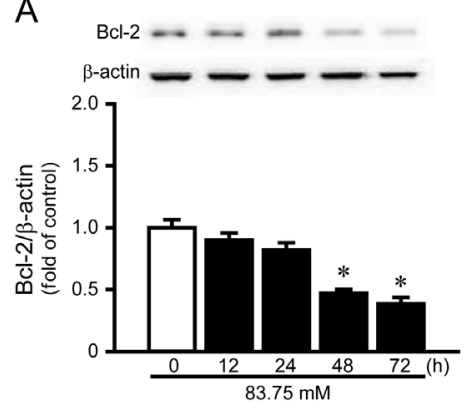

C

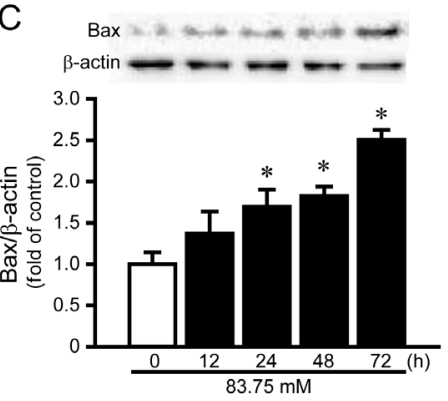

B
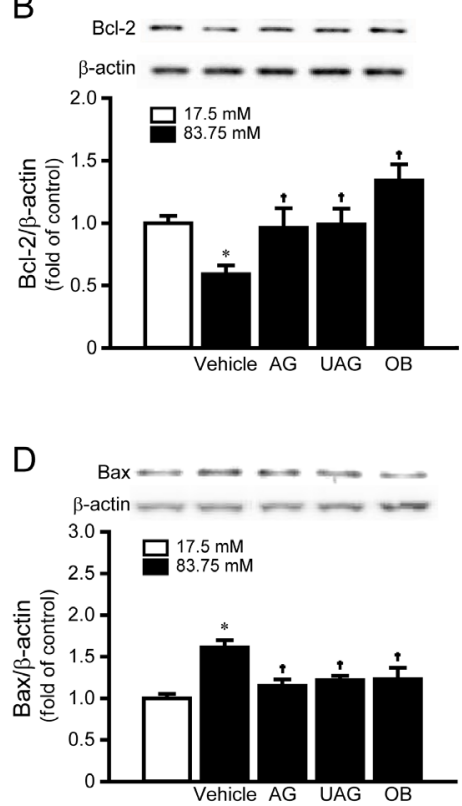

E

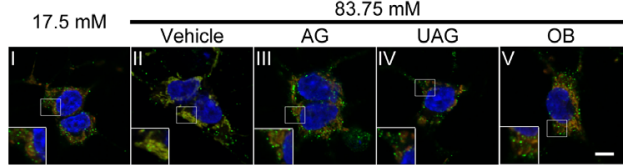

F

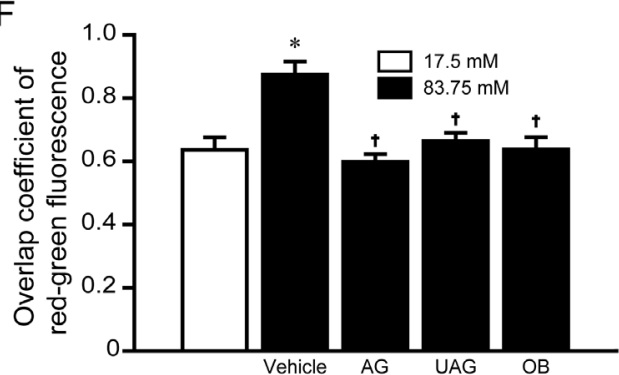

Figure 5

Effects of ghrelin gene products on BCl-2 and Bax levels in hippocampal NSCs exposed to HG insult. (A and C) Cells were exposed to $83.75 \mathrm{mM}$ glucose for $12,24,48$ and $72 \mathrm{~h}$. (B, D, E and F) Cells were pretreated with vehicle, AG (100 nM), UAG (100 nM) or OB (100 nM) for $1.5 \mathrm{~h}$ and then exposed to $83.75 \mathrm{mM}$ glucose for $48 \mathrm{~h}$. Bcl-2 (A and $\mathrm{B}$ ) and $\mathrm{Bax}(\mathrm{C}$ and $\mathrm{D}$ ) protein levels were assessed by Western blot. $\mathrm{BCl}-2$ and $\mathrm{Bax}$ band intensities were normalized to $\beta$-actin intensity. ( $E$ and F) Effect of ghrelin gene products on Bax tanslocation from the cytosol to the mitochondria. At the completion of HG exposure, cells were stained with MitoTracker Orange CMTRos (red) and then probed with Bax antibody (green) to detect subcellular localization of Bax. Nuclei were visualized by staining with DAPI. Representative microscopic images showing immunofluorescent detection of Bax (E). Quantitative analysis for overlap coefficient of red-green fluorescence (F). Values are the mean \pm s.E.M. expressed as fold of control values set to 1 . * $P<0.05 \mathrm{vs} 17.5 \mathrm{mM}$ glucose-treated control; ${ }^{\dagger} P<0.05$ vs vehicle-treated cells exposed to $83.75 \mathrm{mM}$ glucose.

significantly increased Bcl-2 levels (Fig. 5B). We also measured the levels of Bax protein and found that Bax levels were significantly increased in a time-dependent manner when cells were exposed to HG (Fig. 5C). In contrast, AG, UAG or OB decreased Bax protein levels (Fig. 5D), thereby significantly increasing the Bcl-2/Bax ratio. Then, we performed immunofluorescence staining with confocal microscopy to examine the precise subcellular localization of Bax. In normal glucose-treated control cells, Bax (green color) did not colocalize with mitochondria (red color) (Fig. 5E, image I). The yellow merged color indicates the colocalization of Bax and mitochondria when cells were exposed to $83.75 \mathrm{mM}$ glucose (Fig. 5E, image II), suggesting the translocation of Bax from the cytosol to the mitochondria after HG insult. However, pretreatment with AG (Fig. 5E, image III), UAG (Fig. 5E, image IV) or OB (Fig. 5E, image V) decreased HG-induced translocation of Bax. In addition, quantitative colocalization analysis showed that overlap coefficient increased with HG, whereas ghrelin gene products resulted in significantly decreased overlap coefficient values (Fig. 5F).

\section{Effects of ghrelin gene products on cytochrome c release and caspase- 3 activation}

To determine whether ghrelin gene products inhibit cytochrome c release, we conducted Western blots using lysates of hippocampal NSCs. As shown in Fig. 6A, exposure of cells to $83.75 \mathrm{mM}$ glucose resulted in the increase of cytochrome $\mathrm{c}$ in a time-dependent manner, with a significant rise after $24 \mathrm{~h}$ of exposure to HG. In contrast, when cells were pretreated with AG, UAG or OB, HG-induced increase in cytochrome c was significantly reduced (Fig. 6B). These results were confirmed by immunofluorescence confocal microscopy, which showed colocalization of cytochrome c (green) and MitoTracker (red) in vehicle-treated cells (Fig. 6E, image I). In HG-treated cells, we found that green fluorescence (cytochrome c) was remarkably increased and mitochondria were stained with red MitoTracker but no longer stained green for cytochrome c (Fig. 6E, image II), indicating redistribution of cytochrome $\mathrm{c}$ from the mitochondria to the cytosol. Meanwhile, the peptides decreased HG-induced increase in green fluorescence and restored colocalization of

Published by Bioscientifica Ltd 
A

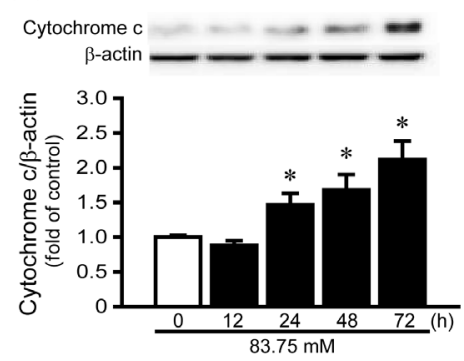

C

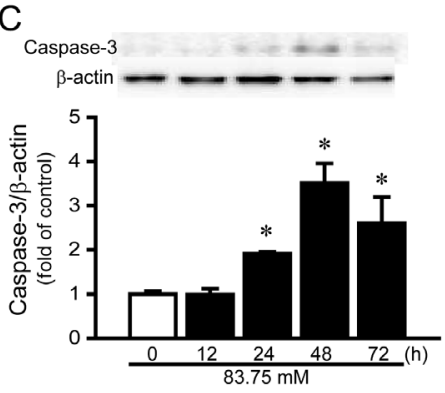

B

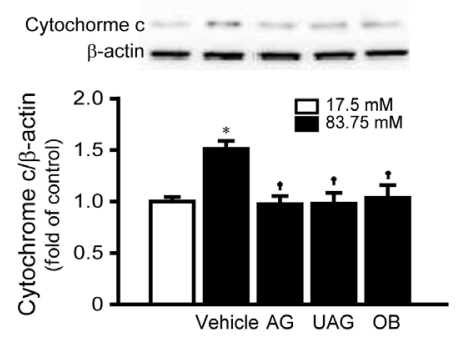

D

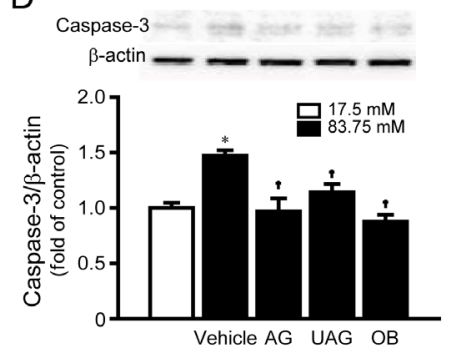

E

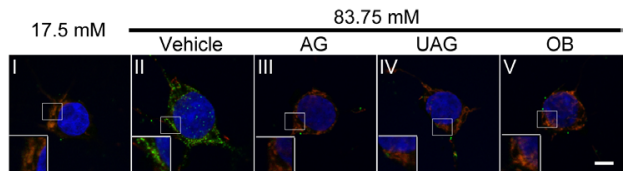

F

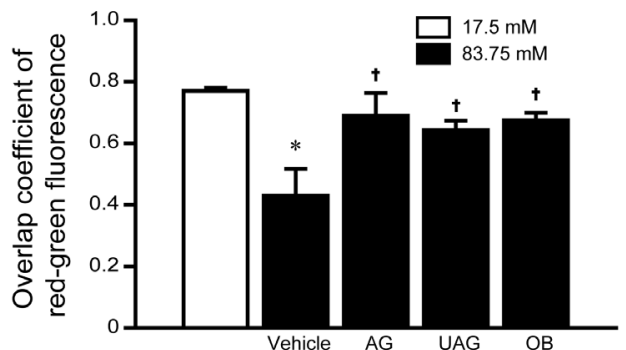

Figure 6

Effects of ghrelin gene products on cytochrome $c$ and active caspase-3 levels in hippocampal NSCs exposed to HG insult. (A and C) Cells were exposed to $83.75 \mathrm{mM}$ glucose for $12,24,48$ and $72 \mathrm{~h}$. (B, D, E and F) Cells were pretreated with vehicle, AG (100 nM), UAG (100 nM) or OB (100 nM) for $1.5 \mathrm{~h}$ and then exposed to $83.75 \mathrm{mM}$ glucose for $48 \mathrm{~h}$. Cytochrome $\mathrm{C}(\mathrm{A}$ and $\mathrm{B}$ ) and active caspase-3 ( $\mathrm{C}$ and $\mathrm{D}$ ) protein levels were assessed by Western blot. Cytochrome $\mathrm{C}$ and caspase-3 band intensities were normalized to $\beta$-actin intensity. (E and F) Effect of ghrelin gene products on cytochrome $c$ release from the mitochondria to the cytosol. At the completion of HG exposure, cells were stained with MitoTracker Orange CMTRos (red) and then probed with cytochrome c antibody (green) to detect subcellular localization of cytochrome c. Nuclei were visualized by staining with DAPI. Representative microscopic images showing immunofluorescent detection of cytochrome c (E). Quantitative analysis for overlap coefficient of red-green fluorescence (F). Values are the mean \pm S.E.M. expressed as fold of control. ${ }^{*} P<0.05$ vs $17.5 \mathrm{mM}$ glucose-treated control; ${ }^{+} P<0.05$ vs vehicle-treated cells exposed to $83.75 \mathrm{mM}$ glucose.

cytochrome c and MitoTracker red staining (Fig. 6E, images III, IV, and V). The overlap coefficient was also calculated to quantify for colocalization of cytochrome c and mitochondria (Fig. 6F). We next investigated whether HG induces caspase-3 activation in hippocampal NSCs and found that there was a time-dependent increase in active caspase- 3 protein levels after exposure to $83.75 \mathrm{mM}$ glucose (Fig. 6C). In contrast, AG, UAG or OB significantly reduced the HG-induced increase in active caspase-3 protein levels (Fig. 6D).

\section{AMPK/UCP2 pathway mediates anti-apoptotic effects of ghrelin gene products against HG insult}

As shown in Fig. 7A and $\mathrm{B}$, in the normal medium with $17.5 \mathrm{mM}$ glucose, ghrelin gene products increased the phosphorylation of AMPK $\alpha$ (p-AMPK $\alpha$ ) and UCP2 expression in a time-dependent manner. Because $\mathrm{HG}$ exposure is known to suppress AMPK activity (Lee et al. 2005), we investigated the effect of AG, UAG or OB on this process. HG treatment significantly decreased p-AMPK $\alpha$ Fig. 7C), whereas treatment of cells with ghrelin gene products increased p-AMPK $\alpha$ protein levels (Fig. 7D). It has been reported that HG exposure induces significant upregulation of UCP2 (Koziel et al. 2015, Urbano et al. 2016). Similar to these findings, we found that $H G$ exposure significantly increased UCP2 expression in a time-dependent manner (Fig. 7E). UCP2 protein levels remained high when cells were treated with AG, UAG or OB (Fig. 7F). To further clarify the mechanisms of ghrelin gene products in inducing anti-apoptotic effect in hippocampal NSCs exposed to HG, we investigated whether pretreatment of cells with the AMPK inhibitor compound $\mathrm{C}$ and UCP2 inhibitor genipin impaired the anti-apoptotic activity of ghrelin gene products against HG toxicity. We found that compound $C$ and genipin significantly blocked the anti-apoptotic effects of $A G$, UAG or OB (Fig. 7G).

\section{Discussion}

In this study, we demonstrate that ghrelin gene products rescue hippocampal NSCs from the apoptotic stimuli of

Published by Bioscientifica Ltd 
A

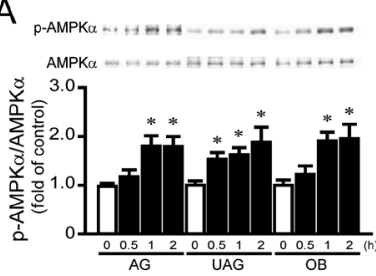

C

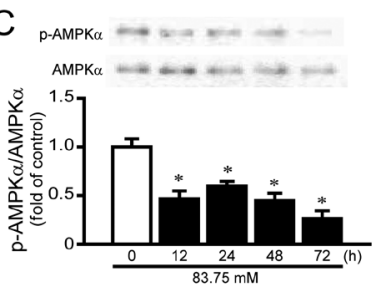

B

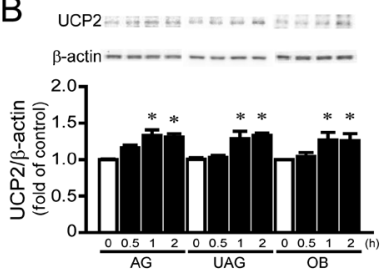

D

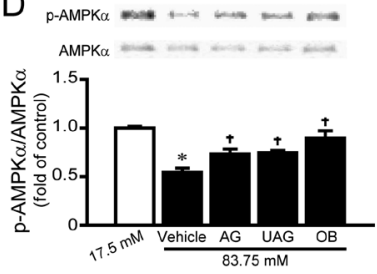

$E$

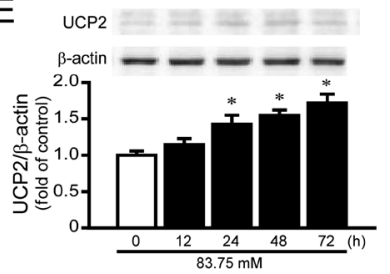

F UCP2

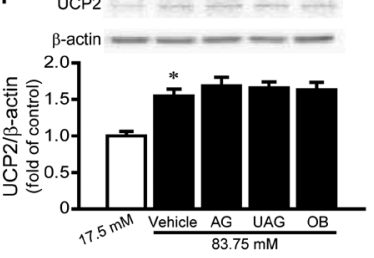

G

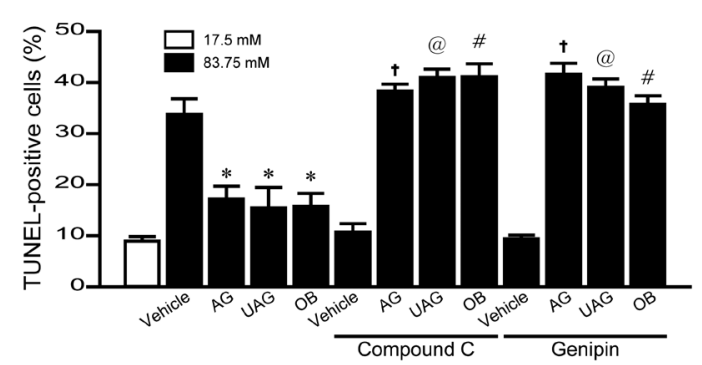

Figure 7

Effects of ghrelin gene products on p-AMPK $\alpha$ and UCP2 levels in hippocampal NSCs exposed to HG insult. (A and B) Cells were treated with AG, UAG or OB for $0.5,1$ or $2 \mathrm{~h}$ in the medium with $17.5 \mathrm{mM}$ glucose. ( $\mathrm{C}$ and $\mathrm{E}$ ) Cells were exposed to $83.75 \mathrm{mM}$ glucose for $12,24,48$ and $72 \mathrm{~h}$. (G) Cells were preincubated with $1 \mu \mathrm{M}$ compound $\mathrm{C}$ and $20 \mu \mathrm{M}$ genipin for $1 \mathrm{~h}$. (D, F and G) Cells were pretreated with vehicle, $A G(100 \mathrm{nM}), \mathrm{UAG}(100 \mathrm{nM})$ or OB $(100 \mathrm{nM})$ for $1.5 \mathrm{~h}$ and then exposed to $83.75 \mathrm{mM}$ glucose for $48 \mathrm{~h}$. Phosphorylated levels of AMPK $\alpha$ ( $A, C$ and $D)$ and UCP2 (B, E and F) protein levels were assessed by Western blot. p-AMPK $\alpha$ and UCP2 band intensities were normalized to total AMPK $\alpha$ and $\beta$-actin intensity, respectively, and expressed as fold of control. ${ }^{*} P<0.05$ vs $17.5 \mathrm{mM}$ glucose-treated control; ${ }^{\dagger} P<0.05$ vs vehicle-treated cells exposed to $83.75 \mathrm{mM}$ glucose. (G) The AMPL/UCP2 pathway mediates the anti-apoptotic effects of AG, UAG or OB. Apoptosis was assessed by TUNEL staining. Values are the mean \pm S.E.M. of four separate experiments performed in triplicate. ${ }^{*} P<0.05$ vs vehicle-treated cells exposed to $83.75 \mathrm{mM}$ glucose; ${ }^{+} P<0.05$ vs $A G$-treated cells exposed to $83.75 \mathrm{mM}$ glucose; ${ }^{\circledR} P<0.05$ vs UAG-treated cells exposed to $83.75 \mathrm{mM}$ glucose; ${ }^{P}<0.05$ vs OB-treated cells exposed to $83.75 \mathrm{mM}$ glucose.

HG insult. It is evident that HG-induced inhibition of NSCs proliferation and mitosis was attenuated by ghrelin gene products. AG-, UAG- or OB-mediated protection was dependent on the activities of AMPK/UCP2 pathway. We showed that ghrelin gene products suppress HG-induced intracellular and mitochondrial ROS production and stabilize $\Delta \Psi_{\mathrm{M}}$. Finally, we present evidence that AG, UAG or $\mathrm{OB}$ alters the status of the Bcl-2 family of proteins, inhibiting cytochrome c release and caspase-3 activity and promoting the survival of hippocampal NSCs exposed to HG.

In this study, we have shown that AG, UAG or OB inhibits apoptosis induced by HG toxicity in hippocampal NSCs. AG is known to exert its effects by activating its functional receptor GHS-R1a, and hippocampal NSCs express GHS-R1a (Chung et al. 2013). The receptor-specific antagonist D-Lys-3-GHRP-6 blocks the protective effect of AG, suggesting the protective effect of AG appears to be mediated through the activation of GHS-R1a. In contrast, anti-apoptotic effect of UAG or OB is likely to be mediated by a separate receptor distinct from GHS-R1a. The existence of independent receptor for UAG is supported by the observation of Toshinai and coworkers (2006), in which UAG, but not AG, increased food intake in GHSR1a-knockout mice. Although the orphan receptor GPR39 was initially thought to bind OB (Zhang et al. 2005), the specific receptor for $\mathrm{OB}$ is still unclear. Recent report suggested the possible involvement of glucagon-like peptide- 1 receptor in the effect of $\mathrm{OB}$ on the proliferation and survival of adult rat hippocampal progenitor cells (Gargantini et al. 2016).

Multiple lines of evidence have demonstrated that ghrelin gene products enhance hippocampal neurogenesis and memory performance (Diano et al. 2006, Moon et al. 2009, Chung et al. 2013, Li et al. 2013a,b, Gargantini et al. 2016). Adult hippocampal neurogenesis is impaired in type 2 diabetes (Lang et al. 2009, Ramos-Rodriguez et al. 2014). It has been implicated that impairment of hippocampal neurogenesis is associated with cognitive dysfunction in type 2 diabetes patients (Ho et al. 2013). In this study, we found that HG exposure resulted in decreases in the numbers of BrdU- and phosphohistone-H3-positive cells, which were attenuated by pretreatment of hippocampal NSCs with AG, UAG or OB. These effects may be important in the enhancement of learning and memory process, because hippocampal-dependent behavioral performance is known to be improved when hippocampal neurogenesis is increased (Kempermann et al. 1997, Fontan-Lozano et al. 2007). Therefore, therapeutic agents targeting the stimulation of adult hippocampal neurogenesis may

Published by Bioscientifica Ltd. 
be plausible candidates for the treatment of cognitive dysfunction observed in patients with type 2 diabetes. These data also suggest that the anti-apoptotic effect, induced by ghrelin gene products, against HG insult may be associated with increased proliferation and mitosis of hippocampal NSCs.

In this study, we have shown for the first time that in hippocampal NSCs, ghrelin gene products prevent HG-induced oxidative stress. Intracellular ROS accumulation plays an important role in the apoptosis of hippocampal neurons after HG exposure (Liu et al. 2014). In agreement with this finding, we found that HG insult significantly increased intracellular ROS levels in hippocampal NSCs. As mitochondria are the main source of intracellular ROS (Indo et al. 2007), we also investigated if HG exposure increased mitochondrial ROS levels and observed that MitoSOX Red fluorescence intensity was significantly increased during $\mathrm{HG}$ exposure. We previously reported that AG suppressed oxygen-glucose deprivation-induced ROS production in hypothalamic neuronal cells (Chung et al. 2007). These results suggest that AG may have antioxidant properties in HG-exposed hippocampal NSCs. To determine whether AG may inhibit HG-induced oxidative stress, we examined the changes in intracellular and mitochondrial ROS levels. Treatment of cells with AG significantly reduced the increase in dichlorofluorescein and MitoSOX Red fluorescence intensity induced by HG. In this study, HG-induced ROS generation was also attenuated by the pretreatment of cells with UAG or OB. Previous studies report that UAG promotes skeletal muscle regeneration after hindlimb ischemia via suppression of ROS (Togliatto et al. 2013) and $\mathrm{OB}$ corrects oxidative imbalance in type 1 diabetic rats (Aragno et al. 2012). Therefore, given the important role of HG-induced oxidative stress in the development of diabetic complications (Baynes \& Thorpe 1999), the ability of these peptides to suppress ROS production seems to be significant for their protective mechanisms against HG insult. The anti-apoptotic protein Bcl-2 may inhibit mitochondrial ROS generation via several mechanisms (Chong et al. 2014), indicating that $\mathrm{Bcl}-2$ protein is a plausible target for the putative antioxidant capacity of AG, UAG or OB. Thus, the increased levels of Bcl-2 protein levels in AG-, UAG- or OB-treated hippocampal NSCs may both contribute to promoting cell survival and protecting against oxidative stress caused by HG insult.

Loss of $\Delta \Psi_{\mathrm{M}}$ is a key event in triggering apoptotic cascade (Green \& Reed 1998). The $\Delta \Psi_{\mathrm{M}}$ is regulated by the PT pore, through which mitochondrial cytochrome c is released. Bcl-2 counteracts apoptosis by conserving the membrane potential and preventing the release of cytochrome c, whereas Bax promotes apoptosis by eliminating the $\Delta \Psi_{\mathrm{M}}$. This concept was supported by our findings that HG resulted in a decrease in Bcl-2 and an increase in Bax levels. In contrast, AG, UAG or OB increased Bcl-2 and decreased Bax levels in HG-treated hippocampal NSCs. In this study, we also observed that ghrelin gene products prevented HG-induced collapse of $\Delta \Psi_{\mathrm{M}}$, suggesting that $\mathrm{AG}$, UAG or $\mathrm{OB}$ may inhibit opening of the mitochondrial PT pore in hippocampal NSCs exposed to HG. Collectively, we propose that these peptides may inhibit HG-mediated production of ROS in hippocampal NSCs and prevent the loss of $\Delta \Psi_{\mathrm{M}}$, thereby preventing the activation of mitochondrial apoptotic cascade mechanism.

The balance between $\mathrm{Bcl}-2$ and Bax can determine the fate of cells (Basu \& Haldar 1998). Bcl-2 gives negative control in the cellular suicide pathway, whereas Bax promotes cell death by competing with Bcl-2. Although Bax and Bcl-2 can form heterodimers and act as anti-apoptotic regulators, Bax-Bax homodimers act as inducers of apoptosis. In this study, we have shown that the Bcl-2/Bax ratio is decreased by HG insult. In contrast, treatment of cells with ghrelin gene products increased $\mathrm{Bcl}-2$ and decreased Bax levels, thereby leading to the restoration of the $\mathrm{Bcl}-2 / \mathrm{Bax}$ ratio. We previously observed similar findings in neuronal cells, in which oxygen-glucose deprivation decreased the Bcl-2/Bax ratio, whereas $A G$ and UAG increased it (Chung et al. 2007, 2008). OB-induced increase in Bcl-2 and decrease in Bax were also observed in human pancreatic islet endothelial cells in hyperglycemic conditions (Favaro et al. 2012). Taken together, in HG-exposed hippocampal NSCs, ghrelin gene products can produce a change in the status of Bcl-2 and Bax proteins that is favorable for cell survival and opposed to induction of the mitochondrial apoptotic process.

During HG-induced apoptosis, cytochrome $\mathrm{c}$ is released from mitochondria due to the opening of the mitochondrial PT pore (Russell et al. 2002). In this study, we have shown that cytochrome c levels are significantly increased in hippocampal NSCs exposed to HG insult. Once cytochrome $\mathrm{c}$ is released from mitochondria into the cytosol, where it can bind to Apaf-1 and activate caspase cascades that induce apoptosis (Green \& Reed 1998). In our previous studies, we found that AG and UAG prevented the oxygen-glucose deprivation-induced release of cytochrome $\mathrm{c}$ and subsequent activation of http://jme.endocrinology-journals.org DOI: 10.1530/JME-16-0096
C 2016 Society for Endocrinology Printed in Great Britain
Published by Bioscientifica Ltd 
caspase-3, inhibiting the activation of the apoptotic cascade (Chung et al. 2007, 2008). Similar to these findings, in this study, we demonstrated that HG-induced increases in cytochrome $\mathrm{c}$ and caspase-3 levels were blocked by treatment of hippocampal NSCs with AG, UAG or OB.

AMPK is an energy sensor that is activated when cellular energy level is low (Ronnett et al. 2009). Aside from being a key regulator in energy balance, AMPK has been shown to play an important role in neuroprotection (Ronnett et al. 2009). It has been reported that HG exposure significantly decreases p-AMPK levels (Lee et al. 2005, Zheng et al. 2015), and AMPK activation sufficiently protects against HG-induced cellular damage (Li et al. 2012, Zheng et al. 2015) and rescues hippocampal neurons from glutamate-induced toxicity (Li et al. 2015). Moreover, it has been shown that AG activates hippocampal AMPK (Kang et al. 2015) and UAG enhances cardiac p-AMPK in $d b / d b$ diabetic mice (Pei et al. 2015). In agreement with these observations, in this study, we found that sustained HG exposure impaired $\mathrm{AMPK} \alpha$ phosphorylation, whereas ghrelin gene products increased the phosphorylation of AMPK $\alpha$ and completely restored HG-induced reduction in $\mathrm{p}$-AMPK $\alpha$ levels. Addition of compound C, an AMPK inhibitor, abolished the anti-apoptotic effect of ghrelin gene products against HG-induced apoptotic cell death. Considering that defective AMPK signaling in neuronal cells is known to be linked to mitochondrial dysfunction and the development of diabetic neuropathy in diabetes patients (Roy Chowdhury et al. 2012), the abilities of ghrelin gene products to attenuate HG-induced suppression of AMPK may contribute to the anti-apoptotic effects of these peptides. We also investigated the effects of these peptides on UCP2 expression in hippocampal NSCs exposed to HG. In agreement with previous studies demonstrating increased UCP2 activity in response to hyperglycemia (Koziel et al. 2015, Urbano et al. 2016), we found that UCP2 protein levels were significantly increased by HG. Enhanced activity of UCP2 in hyperglycemic condition is known to lessen the reduction level of mitochondrial respiratory chain complexes and result in the attenuation of mitochondrial ROS production (Koziel et al. 2015). Therefore, HG-induced increase in UCP2 levels may be associated with improved resistance and protection against oxidative stress caused by HG in hippocampal NSCs. Although there was no further increase in UCP2 levels by AG, UAG or OB treatment in hyperglycemic condition, the findings that ghrelin gene products increased UCP2 expression and chemical inhibition of UCP2 resulted in complete suppression of the anti-apoptotic effects of the peptides, suggesting that UCP2 is required, at least in part, for the actions of ghrelin gene products.

Interestingly, in spite of different functions and characteristics of ghrelin gene products, in this study, all peptides showed basically the same effects. In our previous papers, we have observed that AG and UAG protect cortical neurons in vivo and in vitro through the same mechanisms of action (Chung et al. 2008, Hwang et al. 2009). Specifically, AG and UAG rescue cortical neurons from ischemic injury by inhibiting apoptotic pathways and prostate apoptosis response-4 expression. AG and UAG, independent of acylation, strongly activated Akt and ERK1/2, and the neuroprotective effects of these peptides were mediated by MAPK and PI3K/Akt/glycogen synthase kinase-3 $\beta$ signaling pathways in cortical neurons exposed to oxygen-glucose deprivation. Similar findings were also observed in human pancreatic islet endothelial cells, in which ghrelin gene products and exendin-4 exert cytoprotective effects through the activation of PI3K/Akt, ERK1/2 and cAMP/protein kinase A pathways (Favaro et al. 2012).

In conclusion, our data indicate that ghrelin gene products may act as survival factors that preserve mitochondrial function and inhibit oxidative stressinduced apoptosis. This model is clinically relevant in that sustained hyperglycemia is detrimental to cognitive function (Kodl \& Seaquist 2008) and diabetes-associated decline in cognitive function may be attributed to impaired hippocampal neurogenesis (Stranahan et al. 2008, Zhang et al. 2008, Lang et al. 2009). Therefore, clearance of oxidative stress and improvement of mitochondrial dysfunction by ghrelin gene products may be considered good strategies for the treatment of diabetic neuropathy.

\section{Supplementary data}

This is linked to the online version of the paper at http://dx.doi.org/10.1530/ JME-16-0096.

Declaration of interest

The authors declare that there is no conflict of interest that could be perceived as prejudicing the impartiality of the research reported.

\section{Funding}

This research was supported by the National Research Foundation of Korea (NRF) grant funded by the Korea government (MSIP) (No. 2011-0030072). http://jme.endocrinology-journals.org DOI: 10.1530/JME-16-0096
() 2016 Society for Endocrinology Printed in Great Britain
Published by Bioscientifica Ltd 


\section{Author contribution statement}

Sehee Kim carried out the laboratory experiments, collected the data, and wrote the manuscript. Chanyang Kim carried out the laboratory experiments. Seungjoon Park designed the study, analyzed and interpreted the data, and wrote the manuscript.

\section{References}

Andrews ZB, Liu ZW, Walllingford N, Erion DM, Borok E, Friedman JM, Tschop MH, Shanabrough M, Cline G, Shulman GI, et al. 2008 UCP2 mediates ghrelin's action on NPY/AgRP neurons by lowering free radicals. Nature 454 846-851. (doi:10.1016/j.bcp.2011.03.031)

Aragno M, Mastrocola R, Ghe C, Arnoletti E, Bassino E, Alloatti G \& Muccioli G 2012 Obestatin induced recovery of myocardial dysfunction in type 1 diabetic rats: underlying mechanisms. Cardiovascular Diabetology 11 129. (doi:10.1186/1475-2840-11-129)

Basu A \& Haldar S 1998 The relationship between BcI2, Bax and p53: consequences for cell cycle progression and cell death. Molecular Human Reproduction 4 1099-1109. (doi:10.1073/pnas.0802655105)

Baynes JW \& Thorpe SR 1999 Role of oxidative stress in diabetic complications: a new perspective on an old paradigm. Diabetes $\mathbf{4 8}$ 1-9. (doi:10.1016/0092-8674(95)90385-2)

Chan PH 2004 Mitochondria and neuronal death/survival signaling pathways in cerebral ischemia. Neurochemical Research 29 1943-1949. (doi:10.1038/nrc3262)

Chen J, Guo Y, Cheng W, Chen R, Liu T, Chen Z \& Tan S 2013 High glucose induces apoptosis and suppresses proliferation of adult rat neural stem cells following in vitro ischemia. BMC Neuroscience $\mathbf{1 4}$ 24. (doi:10.1200/JCO.2011.38.3331)

Chong SJ, Low IC \& Pervaiz S 2014 Mitochondrial ROS and involvement of Bcl-2 as a mitochondrial ROS regulator. Mitochondrion 19 39-48. (doi:10.1200/JCO.2012.43.7251)

Chung H, Kim E, Lee DH, Seo S, Ju S, Lee D, Kim H \& Park S 2007 Ghrelin inhibits apoptosis in hypothalamic neuronal cells during oxygen-glucose deprivation. Endocrinology 148 148-159. (doi:10.1210/en.2006-0991)

Chung H, Seo S, Moon M \& Park S 2008 Phosphatidylinositol-3-kinase/ Akt/glycogen synthase kinase- 3 beta and ERK1/2 pathways mediate protective effects of acylated and unacylated ghrelin against oxygenglucose deprivation-induced apoptosis in primary rat cortical neuronal cells. Journal of Endocrinology 198 511-521. (doi:10.1677) JOE-08-0160)

Chung H, Li E, Kim Y, Kim S \& Park S 2013 Multiple signaling pathways mediate ghrelin-induced proliferation of hippocampal neural stem cells. Journal of Endocrinology 218 49-59. (doi:10.1530/JOE-13-0045)

Diano S, Farr SA, Benoit SC, McNay EC, da Silva I, Horvath B, Gaskin FS, Nonaka N, Jaeger LB, Banks WA, et al. 2006 Ghrelin controls hippocampal spine synapse density and memory performance. Nature Neuroscience 9 381-388. (doi:10.1038/nn1656)

Favaro E, Granata R, Miceli I, Baragli A, Settanni F, Cavallo PP, Ghigo E, Camussi G \& Zanone MM 2012 The ghrelin gene products and exendin-4 promote survival of human pancreatic islet endothelial cells in hyperglycaemic conditions, through phosphoinositide 3-kinase/Akt, extracellular signal-related kinase (ERK)1/2 and cAMP/ protein kinase A (PKA) signalling pathways. Diabetologia 55 1058-1070. (doi:10.1007/s00125-011-2423-y)

Fontan-Lozano A, Saez-Cassanelli JL, Inda MC, de los Santos-Arteaga M, Sierra-Dominguez SA, Lopez-Lluch G, gado-Garcia JM \& Carrion AM 2007 Caloric restriction increases learning consolidation and facilitates synaptic plasticity through mechanisms dependent on NR2B subunits of the NMDA receptor. Journal of Neuroscience $\mathbf{2 7}$ 10185-10195. (doi:10.1523/JNEUROSCI.2757-07.2007)

Gahete MD, Rincon-Fernandez D, Villa-Osaba A, Hormaechea-Agulla D, Ibanez-Costa A, Martinez-Fuentes AJ, Gracia-Navarro F, Castano JP \&
Luque RM 2014 Ghrelin gene products, receptors, and GOAT enzyme: biological and pathophysiological insight. Journal of Endocrinology 220 R1-R24. (doi:10.1530/JOE-13-0391)

Gargantini E, Lazzari L, Settanni F, Taliano M, Trovato L, Gesmundo I, Ghigo E \& Granata R 2016 Obestatin promotes proliferation and survival of adult hippocampal progenitors and reduces amyloid-betainduced toxicity. Molecular and Cellular Endocrinology 422 18-30. (doi:10.1016/j.mce.2015.11.008)

Granata R, Settanni F, Gallo D, Trovato L, Biancone L, Cantaluppi V, Nano R, Annunziata M, Campiglia P, Arnoletti E, et al. 2008 Obestatin promotes survival of pancreatic beta-cells and human islets and induces expression of genes involved in the regulation of beta-cell mass and function. Diabetes 57 967-979. (doi:10.2337/ db07-1104)

Green DR \& Reed JC 1998 Mitochondria and apoptosis. Science 281 1309-1312. (doi:10.1126/science.281.5381.1309)

Ho N, Sommers MS \& Lucki I 2013 Effects of diabetes on hippocampal neurogenesis: links to cognition and depression. Neuroscience \& Biobehavioral Reviews 37 1346-1362. (doi:10.1016/j. neubiorev.2013.03.010)

Hosoda H, Kojima M, Matsuo H \& Kangawa K 2000 Ghrelin and desacyl ghrelin: two major forms of rat ghrelin peptide in gastrointestinal tissue. Biochemical and Biophysical Research Communications 279 909-913. (doi:10.1006/bbrc.2000.4039)

Hwang S, Moon M, Kim S, Hwang L, Ahn KJ \& Park S 2009 Neuroprotective effect of ghrelin is associated with decreased expression of prostate apoptosis response-4. Endocrine Journal $\mathbf{5 6}$ 609-617. (doi:10.1507/endocrj.K09E-072)

Indo HP, Davidson M, Yen HC, Suenaga S, Tomita K, Nishii T, Higuchi M, Koga Y, Ozawa T \& Majima HJ 2007 Evidence of ROS generation by mitochondria in cells with impaired electron transport chain and mitochondrial DNA damage. Mitochondrion 7 106-118. (doi:10.1016/j.mito.2006.11.026)

Jiang H, Betancourt L \& Smith RG 2006 Ghrelin amplifies dopamine signaling by cross talk involving formation of growth hormone secretagogue receptor/dopamine receptor subtype 1 heterodimers. Molecular Endocrinology 20 1772-1785. (doi:10.1210/me.2005-0084)

Jiang H, Li LJ, Wang J \& Xie JX 2008 Ghrelin antagonizes MPTP-induced neurotoxicity to the dopaminergic neurons in mouse substantia nigra. Experimental Neurology 212 532-537. (doi:10.1016/j. expneurol.2008.05.006)

Kang S, Moon NR, Kim DS, Kim SH \& Park S 2015 Central acylated ghrelin improves memory function and hippocampal AMPK activation and partly reverses the impairment of energy and glucose metabolism in rats infused with beta-amyloid. Peptides $\mathbf{7 1} 84-93$. (doi:10.1016/j.peptides.2015.07.005)

Kempermann G, Kuhn HG \& Gage FH 1997 More hippocampal neurons in adult mice living in an enriched environment. Nature $\mathbf{3 8 6}$ 493-495. (doi:10.1038/386493a0)

Kodl CT \& Seaquist ER 2008 Cognitive dysfunction and diabetes mellitus. Endocrine Reviews 29 494-511. (doi:10.1210/er.2007-0034)

Kojima M \& Kangawa K 2005 Ghrelin: structure and function. Physiological Reviews 85 495-522. (doi:10.1152/physrev.00012.2004)

Kojima M, Hosoda H, Date Y, Nakazato M, Matsuo H \& Kangawa K 1999 Ghrelin is a growth hormone-relesasing acylated peptide from stomach. Nature $\mathbf{4 0 2}$ 656-660. (doi:10.1038/45230)

Koziel A, Sobieraj I \& Jarmuszkiewicz W 2015 Increased activity of mitochondrial uncoupling protein 2 improves stress resistance in cultured endothelial cells exposed in vitro to high glucose levels. American Journal of Physiology: Heart and Circulatory Physiology 309 H147-H156. (doi:10.1152/ajpheart.00759.2014)

Lang BT, Yan Y, Dempsey RJ \& Vemuganti R 2009 Impaired neurogenesis in adult type-2 diabetic rats. Brain Research 1258 25-33. (doi:10.1016/j.brainres.2008.12.026)

Lee K, Li B, Xi X, Suh Y \& Martin RJ 2005 Role of neuronal energy status in the regulation of adenosine $5^{\prime}$-monophosphate-activated

Published by Bioscientifica Ltd. 
protein kinase, orexigenic neuropeptides expression, and feeding behavior. Endocrinology 146 3-10. (doi:10.1210/en.2004-0968)

Li P, Nijhawan D, Budihardjo I, Srinivasula SM, Ahmad M, Alnemri ES \& Wang X 1997 Cytochrome c and dATP-dependent formation of Apaf-1/caspase- 9 complex initiates an apoptotic protease cascade. Cell 91 479-489. (doi:10.1016/S0092-8674(00)80434-1)

Li FY, Lam KS, Tse HF, Chen C, Wang Y, Vanhoutte PM \& Xu A 2012 Endothelium-selective activation of AMP-activated protein kinase prevents diabetes mellitus-induced impairment in vascular function and reendothelialization via induction of heme oxygenase-1 in mice. Circulation 126 1267-1277. (doi:10.1161/ CIRCULATIONAHA.112.108159)

Li E, Chung H, Kim Y, Kim DH, Ryu JH, Sato T, Kojima M \& Park S $2013 a$ Ghrelin directly stimulates adult hippocampal neurogenesis implications for learning and memory. Endocrine Journal 60 781-789. (doi:10.1507/endocrj.ej13-0008)

Li E, Kim Y, Kim S \& Park S 2013b Ghrelin-induced hippocampal neurogenesis and enhancement of cognitive function are mediated independently of GH/IGF-1 axis: lessons from the spontaneous dwarf rats. Endocrine Journal 60 1065-1075. (doi:10.1507/endocrj. EJ13-0045)

Li Y, Li J, Li S, Li Y, Wang X, Liu B, Fu Q \& Ma S 2015 Curcumin attenuates glutamate neurotoxicity in the hippocampus by suppression of ER stress-associated TXNIP/NLRP3 inflammasome activation in a manner dependent on AMPK. Toxicology and Applied Pharmacology 286 53-63. (doi:10.1016/j.taap.2015.03.010)

Liu Y, Chen L, Xu X, Vicaut E \& Sercombe R 2009 Both ischemic preconditioning and ghrelin administration protect hippocampus from ischemia/reperfusion and upregulate uncoupling protein-2. BMC Physiology 9 17. (doi:10.1186/1472-6793-9-17)

Liu D, Zhang H, Gu W \& Zhang M 2014 Effects of exposure to high glucose on primary cultured hippocampal neurons: involvement of intracellular ROS accumulation. Neurological Sciences 35 831-837. (doi:10.1007/s10072-013-1605-4)

MacGregor DG, Avshalumov MV \& Rice ME 2003 Brain edema induced by in vitro ischemia: causal factors and neuroprotection. Journal of Neurochemistry 85 1402-1411. (doi:10.1046/

j.1471-4159.2003.01772.x)

Miao Y, Xia Q, Hou Z, Zheng Y, Pan H \& Zhu S 2007 Ghrelin protects cortical neuron against focal ischemia/reperfusion in rats. Biochemical and Biophysical Research Communications 359 795-800. (doi:10.1016/j.bbrc.2007.05.192)

Moon M, Kim S, Hwang L \& Park S 2009 Ghrelin regulates hippocampal neurogenesis in adult mice. Endocrine Journal 56 525-531. (doi:10.1507/endocrj.K09E-089)

Nogueiras R, Pfluger P, Tovar S, Arnold M, Mitchell S, Morris A, PerezTilve D, Vazquez MJ, Wiedmer P, Castaneda TR, et al. 2007 Effects of obestatin on energy balance and growth hormone secretion in rodents. Endocrinology 148 21-26. (doi:10.1210/en.2006-0915)

Pei XM, Yung BY, Yip SP, Chan LW, Wong CS, Ying M \& Siu PM 2015 Protective effects of desacyl ghrelin on diabetic cardiomyopathy. Acta Diabetologica 52 293-306. (doi:10.1007/s00592-014-0637-4)

Ramos-Rodriguez JJ, Molina-Gil S, Ortiz-Barajas O, Jimenez-Palomares M, Perdomo G, Cozar-Castellano I, Lechuga-Sancho AM \& GarciaAlloza M 2014 Central proliferation and neurogenesis is impaired in type 2 diabetes and prediabetes animal models. PLOS ONE 9 e89229. (doi:10.1371/journal.pone.0089229)

Ronnett GV, Ramamurthy S, Kleman AM, Landree LE \& Aja S 2009 AMPK in the brain: its roles in energy balance and neuroprotection. Journal of Neurochemistry 109 (Supplement 1) 17-23. (doi:10.1111/j.1471-4159.2009.05916.x)

Roy Chowdhury SK, Smith DR, Saleh A, Schapansky J, Marquez A, Gomes S, Akude E, Morrow D, Calcutt NA \& Fernyhough P 2012 Impaired adenosine monophosphate-activated protein kinase signalling in dorsal root ganglia neurons is linked to mitochondrial dysfunction and peripheral neuropathy in diabetes. Brain 135 1751-1766. (doi:10.1093/brain/aws097)

Russell JW \& Feldman EL 1999 Insulin-like growth factor-I prevents apoptosis in sympathetic neurons exposed to high glucose. Hormone and Metabolic Research 31 90-96. (doi:10.1055/s-2007-978704)

Russell JW, Sullivan KA, Windebank AJ, Herrmann DN \& Feldman EL 1999 Neurons undergo apoptosis in animal and cell culture models of diabetes. Neurobiology of Disease 6 347-363. (doi:10.1006/ nbdi.1999.0254)

Russell JW, Golovoy D, Vincent AM, Mahendru P, Olzmann JA, Mentzer A \& Feldman EL 2002 High glucose-induced oxidative stress and mitochondrial dysfunction in neurons. FASEB Journal 16 1738-1748. (doi:10.1096/fj.01-1027com)

Sato M, Nakahara K, Goto S, Kaiya H, Miyazato M, Date Y, Nakazato M, Kangawa K \& Murakami N 2006 Effects of ghrelin and des-acyl ghrelin on neurogenesis of the rat fetal spinal cord. Biochemical and Biophysical Research Communications 350 598-603. (doi:10.1016/j. bbrc.2006.09.088)

Shen CC, Huang HM, Ou HC, Chen HL, Chen WC \& Jeng KC 2004 Protective effect of nicotinamide on neuronal cells under oxygen and glucose deprivation and hypoxia/reoxygenation. Journal of Biomedical Science 11 472-481. (doi:10.1007/BF02256096)

Srinivasan S, Stevens M \& Wiley JW 2000 Diabetic peripheral neuropathy: evidence for apoptosis and associated mitochondrial dysfunction. Diabetes 49 1932-1938. (doi:10.2337/ diabetes.49.11.1932)

Stranahan AM, Arumugam TV, Cutler RG, Lee K, Egan JM \& Mattson MP 2008 Diabetes impairs hippocampal function through glucocorticoid-mediated effects on new and mature neurons. Nature Neuroscience 11 309-317. (doi:10.1038/nn2055)

Tabakman R, Lazarovici P \& Kohen R 2002 Neuroprotective effects of carnosine and homocarnosine on pheochromocytoma PC12 cells exposed to ischemia. Journal of Neuroscience Research 68 463-469. (doi:10.1002/jnr.10228)

Togliatto G, Trombetta A, Dentelli P, Cotogni P, Rosso A, Tschop MH, Granata R, Ghigo E \& Brizzi MF 2013 Unacylated ghrelin promotes skeletal muscle regeneration following hindlimb ischemia via SOD-2mediated miR-221/222 expression. Journal of the American Heart Association 2 e000376. (doi:10.1161/JAHA.113.000376)

Toshinai K, Yamaguchi H, Sun Y, Smith RG, Yamanaka A, Sakurai T, Date Y, Mondal MS, Shimbara T, Kawagoe T, et al. 2006 Des-acyl ghrelin induces food intake by a mechanism independent of the growth hormone secretagogue receptor. Endocrinology 147 2306-2314. (doi:10.1210/en.2005-1357)

Tschop M, Smiley DL \& Heiman ML 2000 Ghrelin induces adiposity in rodents. Nature 407 908-913. (doi:10.1038/35038090)

Urbano F, Filippello A, Di PA, Barbagallo D, Di MS, Pappalardo A, Rabuazzo AM, Purrello M, Purrello F \& Piro S 2016 Altered expression of uncoupling protein 2 in GLP-1-producing cells after chronic high glucose exposure: implications for the pathogenesis of diabetes mellitus. American Journal of Physiology: Cell Physiology 31D C558-C567. (doi:10.1152/ajpcell.00148.2015)

Van der Lely AJ, Tschop M, Heiman ML \& Ghigo E 2004 Biological, physiological, pathophysiological, and pharmacological aspects of ghrelin. Endocrine Reviews 25 426-457. (doi:10.1210/er.2002-0029)

Voloboueva LA \& Giffard RG 2011 Inflammation, mitochondria, and the inhibition of adult neurogenesis. Journal of Neuroscience Research 89 1989-1996. (doi:10.1002/jnr.22768)

Wren AM, Ward HL, Murphy LJ, Dakin CI, Taheri S, Kennedy AR, Roberst GH, Morgan DGA, Ghatei MA \& Bloom SR 2000 The novel hypothlamic peptide ghrelin stimulates food intake and growth hormone secretion. Endocrinology 141 4325-4328. (doi:10.1210/ endo.141.11.7873) http://jme.endocrinology-journals.org

DOI: 10.1530/JME-16-0096
() 2016 Society for Endocrinology Printed in Great Britain
Published by Bioscientifica Ltd 
Yoshida H, Kong YY, Yoshida R, Elia AJ, Hakem A, Hakem R, Penninger JM \& Mak TW 1998 Apaf1 is required for mitochondrial pathways of apoptosis and brain development. Cell 94 739-750. (doi:10.1016/S0092-8674(00)81733-X)

Zhang JV, Ren PG, vsian-Kretchmer O, Luo CW, Rauch R, Klein C \& Hsueh AJ 2005 Obestatin, a peptide encoded by the ghrelin gene, opposes ghrelin's effects on food intake. Science 310 996-999. (doi:10.1126/science.1117255)

Zhang WJ, Tan YF, Yue JT, Vranic M \& Wojtowicz JM 2008 Impairment of hippocampal neurogenesis in streptozotocin-treated diabetic rats.
Acta Neurologica Scandinavica 117 205-210.

(doi:10.1111/j.1600-0404.2007.00928.x)

Zhao C, Deng W \& Gage FH 2008 Mechanisms and functional implications of adult neurogenesis. Cell 132 645-660. (doi:10.1016/j. cell.2008.01.033)

Zheng A, Li H, Xu J, Cao K, Li H, Pu W, Yang Z, Peng Y, Long J, Liu J \& Feng Z 2015 Hydroxytyrosol improves mitochondrial function and reduces oxidative stress in the brain of $\mathrm{db} / \mathrm{db}$ mice: role of AMPactivated protein kinase activation. British Journal of Nutrition $\mathbf{1 1 3}$ 1667-1676. (doi:10.1017/S0007114515000884)

Received in final form 4 August 2016

Accepted 16 August 2016

Accepted Preprint published online 16 August 2016
Published by Bioscientifica Ltd. 